\title{
KOMPARATIV LITTERATURHISTORIE I DET UDVIDEDE FELT STILLEHAVET SOM CASE
}

\section{KOMPARATIV LITTERATURHISTORIE I DET UDVIDEDE FELT. STILLEHAVET SOM}

CASE | The article discusses status and perspectives for writing literary history based on an updated model for comparative literature. While the American re-launching of World Literature is not regarded to be a useful response to the global challenges facing literary historiography, it is proposed to re-evaluate the long history of comparatism in order to find models that match the current situation of literature in the expanded field. The article investigates narratives on expeditions in the Pacific Ocean from the 18th century. Here are outlined two models for comparison: One that leads toward cultural relativism and its problematic tendency to describe the compared societies as autonomous and closed, and another model, which can serve as a point of departure for grasping literature in both its historical and global conditions.

KEYWORDS | comparative literature, pacific literature, world literature, comparatism, cultural relativism, pacific exploration

De seneste år er der udgivet en række ambitiøse og store litteraturhistoriske værker i Danmark, hvilket kunne tyde på, at disciplinen og genren stortrives. Det er forståeligt, at historiens genkomst i oplevelsesøkonomien og det øgede fokus på kanon og tradition gennem hele uddannelsessystemets litteraturundervisning har givet forlæggere blod på tanden, men det er samtidig bemærkelsesværdigt, at værkernes litteraturhistoriografiske grundlag kun i meget ringe grad har været til debat. Udgivelserne viser, at det er muligt at skrive litteraturhistorie ved faktisk at gøre det, selvom det for længe siden er blevet påvist, at det er en teoretisk umulighed (Sørensen, Perkins). De demonstrerer implicit også, at litteraturhistorieskrivning ikke er videnskab, men formidling, og måske skyldes tavsheden om metode simpelthen en forlegenhed over for at vedstå sig denne pinlige kendsgerning? Problemet er imidlertid, at en litteraturhistorieskrivning, der ikke reflekterer sine grundlæggende begreber om litteratur, værk og historie, ender med at blive livløs repetition og udstilling af tradition. H.R. Jauss formulerede det programmatisk i 1967 i artiklen "Litteraturhistorie som udfordring til litteraturvidenskab": Det gælder til enhver tid om at reflektere litteraturhistorieskrivningens grundlag med afsæt i udfordringerne i den aktuelle litterære kultur. Jauss argumenterede den- 
gang for en litteraturhistorisk hermeneutik baseret på antagelsen om litteraturens relative autonomi, men i dag må grundlag og metode naturligvis være anderledes, fordi litteraturens situation helt grundlæggende er forandret.

Både forskning, formidling og undervisning i litteraturhistorie siden Jauss og den æstetiske vending i I980'erne har været baseret på analyser af autonome enkeltværker, trods de uforenelige perspektiver heri. I det følgende er afsættet, at en genfødsel af litteraturhistoriefaget kan ske ved en tilbagevenden til fundamentet i den komparative tradition, nu blot på "postlitterære betingelser", dvs. ud fra den grundlæggende omkalfatring af det litterære system, der sker i disse år: Udviklingen af nye medier og globaliseringen af det litterære marked medfører ikke kun nye litterære platforme og funktionsmåder, men ændrer hele det litterære felt. Tekstformer, forfatterroller og læsemønstre har i dag mere til fælles med I700-tallets heteronome litterære kultur end med den relative autonomi, som længe er blevet opfattet som den i al evighed dominerende institutionalisering af litteraturen. Markedet, medierne og globaliseringen har gennemført den ophævelse af autonomien, som avantgarde- og neoavantgardebevægelserne drømte om. Performativitetsstudier, $ø$ kokritik, fiktionalitetsteori og ny narratologi anfægter på tilsvarende vis de nyklassiske opfattelser af enkeltværket som litteraturvidenskabens omdrejningspunkt, hvilket i praksis har defineret litteraturstudier og litteraturhistorieskrivning siden nykritikken, og problematiserer forudsætningerne for formalistisk og hermeneutisk metode.

Prosastudier i både nutidens litterære kultur og ældre litteratur udfordrer skillelinjer mellem sagprosa og skønlitteratur og mellem fin- og masselitteratur, og globaliseringsperspektivet retter opmærksomheden på, at det litteraturbegreb, som det litteraturhistoriske kanonsystem hviler på, kun har en historisk kortvarig og geografisk begrænset gyldighed. Den vidnesbyrdsbaserede litteraturhistorieskrivning, der i de senere år har vundet frem, har desuden vist sig at være problematisk, når den ophøjer øjenvidnets beretning og favoriserer den enkeltstående teksts autenticitet: En historieskrivning må være forpligtet på at opsøge og komparere de andre vidnesbyrd, de tekster i arkivet, som den efterfølgende erindringskultur ikke har privilegeret.

\section{Komparativ litteraturforskning - igen}

Komparativ litteraturforskning søger forklaringssammenhænge i litteraturhistorien på tværs af nationallitteraturer og på tværs af enkeltværker. Det første træk giver en traditionssammenhæng med feltet Verdenslitteratur, som i dag har succes i USA som universitetsdisciplin og curriculum, men som snarere skal ses som et ambitiøst forsøg på både at forvalte kanon og kanonkritik end som litteraturhistorieskrivning. For det andet er der tale om et fællesskab med en lang række i øvrigt stærkt forskellige traditioner i det 20. århundrede, fra russisk formalisme til strukturalisme og diskursanalyse, med disses vægtning af, at det er de tværgående modeller og mønstre, som fremkommer gennem sammenligningen, der er fagets genstand, ikke 
de enkelte værker. Franco Morettis forslag om, at forsøg på at finde tværgående mønstre i verdenslitteraturen, f.eks. 'bølgen', nødvendigvis må ske gennem såkaldt "distant reading”, kan derfor ses som et forsøg på at opdatere den komparative metode og samtidig forene to hovedspor i den litterære kritiks historie. Morettis teser har imidlertid kun haft begrænset praktisk betydning, formentlig fordi han hverken leverer gode nærlæsninger eller overbevisende litteraturhistorieskrivning.

I Danmark og Norge, i mindre grad Sverige og Finland, har komparatismen været fortrængt af de bølger af teori, som de sidste 50 år er skyllet ind over litteraturinstitutterne, selvom de fortsat præsenterer sig som afdelinger for "Comparative Literature”, når de er udenbys (Dahl og Larsen). I håndbogen Litteratur. Introduktion til teori og analyse fra 2012 er der ingen opslag om komparatismen og i andre teorioversigter beskrives fænomenet typisk som en aldeles død sild, selvom udgivelser og konferencer organiseret af den internationale organisation ICLA udviser et stort spektrum af forskning inden for det komparative fagområde, dog med klar overrepræsentation fra de romanske sprogområder, de tidligere østlande og Asien, og typisk uden at problematisere det komparative udgangspunkt. I forbindelse med de rapporter, der med Io års mellemrum udsendes af den amerikanske organisation, ACLA, forsøger man faktisk at diskutere disciplinens grundlag, genstand og metode - som regel under indtryk af en altgennemgribende krise, der blandt andet viser sig ved disciplinens tilbagegang på universiteterne, indfældning eller opløsning i andre fag.

ACLA-rapporten fra 1993, "Comparative Literature in the Age of Multiculturalism”, beskrev den komparative litteraturhistories krise som en konflikt mellem på den ene side dem, der praktiserede en enorm udvidelse af genstandsfeltet til også at omfatte såkaldte "globale kulturstudier", hvor litteratur kun var én diskurs ved siden af filosofiske, psykologiske, medicinske, juridiske diskurser samt film og populær kultur osv., og på den anden side dem, der ville fastholde den enkelte litterære tekst som litteraturvidenskabens primære genstand. (Bernheimer). I ACLA-rapporten fra 2006 er konflikten mellem kulturstudier og studier af litterære værker erstattet af en diskussion, om og hvordan komparativ litteratur skal forholde sig til feltet verdenslitteratur, der på det tidspunkt bredte sig på de amerikanske universiteter. Fordi verdenslitteratur tilsyneladende både rummer det globale kulturstudie og holder det enkelte litterære værk i fokus, har begrebet kunnet forsone den tidligere konflikt. Men som bl.a. Nathalie Melas og Jonathan Culler har peget på, løses konflikten med den omkostning, at de sammenlignede værker i praksis tilhører kanon og hyperkanon, som er den skjulte standard, der etablerer sammenligningen. I mit perspektiv mistes desuden den tværvidenskabelige og tværdiskursive bestræbelse på at læse litteraturen i "det udvidede felt", som der var ansatser til, bl.a. med Edward Saids Orientalism eller Stephen Greenblatts Marvelous Possessions som omdiskuterede forbilleder. Komparativ litteratur bedrevet som verdenslitteratur fører ironisk nok til en provinsiel litteraturhistorieskrivning, der er ude af trit med den litterære eller nærmere post-litterære kultur både i Vesten og i Kina (Huyssen). 
Haun Saussy og Culler har begge foreslået, at opgaven i stedet kan formuleres som en bestræbelse på at læse "litterært", dvs. med alle de forståelser af teksters retoriske kompleksitet, der dyrkes i litteraturvidenskabens "close reading", men i et genstandsfelt, der inkluderer det tidligere nævnte brede felt af diskurser, genrer og medier (Saussy, Culler). Over for indvendingen om genstandens principielle uafgrænselighed henviser Culler til Erich Auerbachs begreb om "Ansatzpunkt", dvs. en pragmatisk afgrænsning og eksplicitering af metode, som gør det muligt at udføre sammenligninger $i$ et heterogent og bredt sammensat kulturelt felt. Auerbach skriver, at et godt "Ansatzpunkt” er karakteriseret ved at være konkret og præcist og samtidig med stort potentiale for centrifugal "udstrålende" udbredelse. En metode, ikke en teori, som Auerbach selv har demonstreret rækkevidden af i sit litteraturhistoriografiske mesterværk Mimesis (1946), der på tværs af skillelinjer mellem genrer og diskurser fremlæser grundlæggende litteraturhistoriske udviklingsmønstre gennem nærlæsninger og sammenligninger af udvalgte passager ikke enkeltværker. - Og en metode, der er meget lig den, som Finn Stein Larsen fremlægger i sin introduktion til Prosaens mønstre (I97I), hvor det understreges, at læsningerne ikke følger nykritikkens dogme om at holde sig til enkeltværket, men søger den "modeldannende enhed" i det litterære mønster, som findes på tværs af en række tekster. Man kan derfor også kalde denne form for komparation for ægte strukturalistisk, da den som bl.a. Michel Serres har fremhævet ikke leder efter strukturer $i$ et værk, hvad der ikke giver mening, men studerer struktur i form af de modeller, der kan beskrives som gentagelser af "isomorfe" mønstre mellem og på tværs af tekster, fabler og diskurser. F.eks. beskriver Serres termodynamikkens brændselsmotor som model i tekster af Carnot, Zola, Marx, Freud og Nietzsche eller kortlægger fikspunktet som model i I70o-tallets mekanik, differentialregning og encyklopædi. Pointen er, at målet for analysen ikke er den enkelte tekst, men den struktur, der bevares i sammenligningen.

En af de mest vedholdende kritikker af komparativ litteratur i USA er, at disciplinen gennem de seneste 50 år har mistet sin identitet ved alt for hurtigt at omfavne og applicere ny teori fra hele det omgivende universitet. Et forhold som Murray Krieger karakteriserede som et evigt kapløb om at være den første med det sidste - "the new, the newer og the newest", men også "the post-" og "post-newest", f.eks. "the post-New Critical" - og som en underkastelse under det han kaldte en "as if'-struktur: En både heroisk og komisk forestilling om, at det lod sig gøre at finde den ultimative og universelle teori for litteraturvidenskaben, hvilket tilførte et utopisk lys og en teori-avantgardistisk ånd til udøverne, som tilmed kunne fremstille sig som forerhunde $\mathrm{i}$ forhold til de mindre teoritunge nationallitterære kolleger (Krieger). Mens komparativ litteraturforskning således triumferede som teori og litteraturvidenskab, mistede disciplinen samtidig forbindelsen til sin lange komparative og litteraturhistoriografiske tradition, hvad der i talrige statusopgørelser beskrives som et fuldstændigt tab af faglig identitet. En situation, der forstærkes af, at 'teori' dels ikke længere har den samme magiske kraft, dels at avantgarderollen for komparativ litteratur i relation til andre humanistiske fag længe har været et 
overstået kapitel. Som nævnt tilbød begrebet og feltet verdenslitteratur sig som en løsning på dette identitetstab og foreløbigt med succes som undervisnings- og formidlingsdisciplin, men fortsat uden at give overbevisende bud på en metode for litteraturhistorieskrivning.

Mit forslag er, at en genopbygning af faglig identitet, som tager bestik af samtidens performative, medialiserede og globaliserede litterære kultur, kan ske ved en opdatering af litteraturvidenskabens grundlag i den komparative tradition. "Moderne og sammenlignende litteratur", som faget hed engang, behøver ikke vælge mellem på den ene side nærlæsning og litteratur og på den anden side fjernlæsning og kulturstudier, men gøre begge dele, dvs. udføre nærlæsninger og sammenligninger af litteratur ' $i$ det udvidede felt'. Litteratur i det udvidede felt er ikke kun mængder af enkeltværker, men også fortællinger og narrativitet, uden definitiv narrativ struktur, og begivenheder $i$ et netværk, hvis uigennemtrængeligheder og knudepunkter, det drejer sig om at beskrive og forstå. I det følgende vil jeg i et historisk materiale udskille tidlige former for komparativ metode, som også i dag tegner grundlæggende forskellige modeller for litteraturhistorieskrivning på globale betingelser. Forslaget hviler på en strukturel analogi eller parallelisering mellem sammenligninger af samfund og sammenligninger af værker.

I den sidste halvdel af I70o-tallet blev Stillehavet kortlagt af spanske, franske, hollandske, russiske og engelske ekspeditioner. Især takket være James Cooks tre ekspeditioner og hans forsøg på at lokalisere det sagnomspundne Terra Australis blev oceanet gennemtrawlet, og stillehavsøerne blev beskrevet i de rejsendes dagbøger og i romaner, malerier, digte, pamfletter, traktater, tapeter, teaterstykker og musicals - et tæp pe af begivenheder og fortællinger eller netop 'litteratur i det udvidede felt'. Som også tidligere blev stillehavsøernes samfund, sæder og skikke sammenlignet med de europæiske, men nu skete sammenligningerne også i en gensidig prægning og profilering af nationale idealtyper. Desuden førte kortlægningen af Stillehavet til et vigtigt epistemologisk spring, da kloden nu for første gang kunne beskrives som en empirisk totalitet, hvor verdensdelene erkendes som kontinenter, og de forskellige samfund beskrives som "nationer" ud fra en "planetarisk bevidsthed" (Pratt). Denne sammenkitning af verden skaber grundlag for dels at tænke kloden globalt i det, som er blevet kaldt "the global eighteenth century", dels at udvikle en sammenlignende diskurs om nationer og deres forskellige trin på udviklingsstigen (Nussbaum). Gennem læsninger i det enorme materiale kan man imidlertid udskille to prototyper for komparation, hvoraf den ene, de såkaldte "pastorale komparationer", kan gælde som forbillede for udviklingen af en nykomparatisme på globale og postlitterære betingelser, mens den anden, hvad jeg her kalder for "kulturrelativistisk komparation", tegner en form for komparation mellem sluttede helheder, der i litteraturstudiet i dag er problematisk. 


\section{Pastorale komparationer}

Louis Bougainville ankommer til Tahiti den I. april I768, året efter englænderne 'opdagede' øen.

Bougainville beskriver det første møde som et slør, der trækkes til side og åbenbarer kanoer fyldt med tahitianske kvinder, som i skønhed kan konkurrere med de fleste europæiske. På en vandring bliver de opholdt af en øbo, som hviler under et træ, og som inviterer dem til at tage plads for at nyde en koncert med "anakreontisk" sang til akkompagnement fra en fløjte, som en anden "indianer" spiller på gennem næsen - "en charmerende scene, der kunne fortjene at blive malet af Boucher".

Og ved afrejsen, da Bougainville ikke kan modstå lejligheden til i dagbogen at prise denne lykkelige $\varnothing$ endnu engang, er det med henvisning til denne perfekte balance mellem samfund og natur, som giver tilskueren både ro og nydelse: "Lovgivere og filosoffer, kom her og se alt det, som I i jeres fantasi ikke har kunnet drømme jer til. [...] Det vil altid være med en følelse af glæde, at jeg husker tilbage på den korte tid, jeg tilbragte blandt jer, og, så længe jeg lever, skal jeg lovprise Cythéras lykkelige ø. Den er den sande Eutopi” (Bougainville I77I: 73-74).

I overensstemmelse med konventionerne i den klassiske utopi er naturforestillingen mere rettet bagud end fremad. Utopien søger snarere sine forbilleder i et idealiseret landbrugssamfund end i de samfundsmæssige muligheder, der åbnes med industrialiseringen $\mathrm{i}$ begyndelsen af I70o-tallet. Bougainvilles lovprisning af Tahiti og dens primitivistiske og rousseauske inspiration kan ses som en kritik af moderniteten og de spaltninger, den fører med sig. På denne ø er alt i harmoni med naturen, samfundet er protoøkologisk og protokommunistisk og dog indrettet helt efter de aristokratiske idealer i l'ancien regime, som Bougainville repræsenterede både med sin person og sin rejse.

På samme måde som de rokokomalerier af François Boucher, som Bougainville refererer til som forbilleder, er den pastorale fortælling uden centralperspektiv, uden noget klimaks i fortællingens horisont, men netop en leg med former, visuelle nydelser og kulturelle betydninger af køn og genre (Hyde I3). Og netop i den sammenhæng er det værd at bemærke Bougainvilles karakteristik af øen som Eutopi, ikke Utopi.

I Thomas Mores benævnelse "utopia” rummes en etymologisk tvivl, nemlig om der refereres til "ou-topos”, dvs. "ikke-sted”, et sted, der ikke findes, eller om referencen gælder "eu-topos”, dvs. "stedet hvor alt er godt". En tilsvarende tvivl synes at være på spil i franskmændenes dagbøger og breve. Naturhistorikeren Commerson skriver bl.a., at han har givet denne ø navnet "Utopie ou de fortunée", før han blev vidende om, at Bougainville havde kaldt den La nouvelle Cythère og senere var blevet belært om, at dens egne beboere kalder stedet for "Taïti" (Bougainville II 402). Allerede i navnespillet er der flere konkurrerende topografier på spil: Tahiti som et sted i den virkelige verden, en geografisk og antropologisk realitet: La nouvelle Cythère, som refererer til et fortidigt Arkadien beskrevet af Vergil og 
en lang tradition af pastorale og anakreontiske digtere. Men også, som dagbogen bevidner det, på bemærkelsesværdig vis en pastoral livsform, der ikke er fundet, men opfundet; samt altså både en eutopi i betydningen et eksisterende lykkeligt sted, der kan virke som filosofisk forbillede og samfundsmodel, og som $u$ topi i betydningen en ikke eksisterende, fortalt og fiktionaliseret verden.

Under sin åbenlyse kunstighed og sin påstand om evig, uforanderlig harmoni med naturen tematiserer pastoralen i letgenkendelig forklædning de storbyproblematikker og de normer og normbrud, der er samtaleemne i salonernes forfinede retorik. Pastoralen adresserer i høj grad både tidslige og rumlige struktureringsprocesser som ødelæggende og uharmoniske, dette at fremskridtet uundgåeligt skaber afstand til naturen og mere unatur, og at det fællesskab som signaleres i figuren 'hyrden som kunstner og kunstneren som hyrde' uigenkaldeligt er mistet. På samme måde som hyrdedigtningen kun befinder sig i naturen på skrømt og altid har byen som horisont, rummer Bougainvilles beskrivelse af Tahiti både et her og et der: Et perspektiv mod det uopnåelige sted, han fra storbyen længes imod, og en paradoksal erfaring på stedet af, at det er alt, hvad han har drømt om, og samtidig - med forudanelsen om en ødelæggende påvirkning fra europæerne - allerede ikke længere er, hvad det var engang.

Oplysningsfilosoffen Diderot skriver en positiv anmeldelse af Bougainvilles beretning, da den udkommer i I77I. Anmeldelsen bliver ikke udgivet, men danner baggrund for, at Diderot i I774 skriver teksten, tilføjelsen og dialogen Supplément au Voyage de Bongainville, ou dialogue entre $A$ et $B$, som cirkulerer i salonerne, men først udgives i 1798 .

Et sted i Diderots tilføjelse taler B om en af de mange varianter af modstillingen mellem naturlige og unaturlige skikke. Tahitianerne rødmer ikke og er ikke pinligt berørte over at blive set eller være vidner til sex. Men B fortsætter med et billede, der synes at mediere modsætningen mellem naturlige og kokette kvinder i henholdsvis Tahiti og Paris: "Når jeg ser træer, som er plantet omkring vores palæer, og et sjal om halsen på en kvinde, som både skjuler og udstiller hendes bryst, forekommer det mig, at jeg genkender en hemmelig vej tilbage til skoven” (Diderot 508). Diderots tekst både opretholder og forskyder en modsætning mellem civilisation og natur og indføjer med dette billede en model for sammenligninger mellem forskellige steders sæder og skikke, som kan være forbillede for både antropologi og litterær komparation i dag: I selve sit koketteri og sin flirt afslører den parisiske Venus en flig af sit eget væsen som naturlig tahitiansk Venus eller civilisationen gemmer i sig og fremviser sin oprindelige natur, ligesom en halvnøgen barm på én gang er koket og naturlig. Kritikken er kritisk skelnende uden at operere med absolutte modsætninger, og sammenligningen søger en 'strukturalistisk' model uden at forudsætte autonome kulturer eller tekster.

Diderots Supplément au Voyage de Bongainville forholder sig kritisk, men ikke udraderende kritisk, til skikke og sæder i Europa og i Tahiti. Universalistiske synspunkter fremstår snæversynede og etnocentriske, mens omvendt en kulturrelativistisk tanke om en tahitiansk selvberoende og autonom kultur også er tek- 
sten fremmed. Alle skikke i alle kulturer kan - hver for sig - til enhver tid gøres til genstand for fornuftig kritik, men uden at sætte de to kulturer over for hinanden, som om de var essentielt forskellige. Og specielt med hensyn til Rousseaus tanke om, at civilisationen uundgåeligt bringer sig på stadig større afstand af naturen, hvilket jo er doktrinen bag f.eks. Commersons beskrivelse af Tahiti som virkeliggjort utopi, så minder Diderot om, at civilisationen altid under sine fremskridt medbringer sin egen natur, som skjuler og viser sig og lover en hemmelig vej tilbage. Utopien afvises på den anden side ikke fuldstændigt, men lokaliseres som en $\varnothing$, der er forbundet med andre øer og kontinenter.

Tilsvarende er den pastorale hos Bougainville, som Diderots læsning hviler på, ikke simpel eller blot ideologisk forvrængning af Tahitis egentlige natur. Hos Bougainville er Vergils Arkadien og hans egne senere tilføjede etnografiske observationer fastholdt som to sideordnede perspektiver, hvilket udlægger grunden for Diderots dialoger. Og selvom pastoralen altid vægter harmonien mellem menneske og natur, rummer den i sine forklædningsspil netop den bevægelighed og reversibilitet, som Diderot bringer frem til overfladen i sin sammenstilling af den galante Venus i Paris over for den frugtbare Venus på Tahiti. Pastoralen er i rokokotraditionen desuden fyldt med de anekdoter og uafsluttede pikante fortællinger, som vi ser videreført i dialogen mellem A og B, ligesom pastoralens spil mellem bykultur/ Paris og hyrdekultur/Tahiti er gentaget hos Diderot.

Pastoralen formulerer det komplekse, f.eks. ændringer i normer for seksuelle relationer, i simple og stærkt kodificerede landskaber og handlingsforløb, men uden at det komplekse er forsvundet - det spiller med i antydninger og ufuldførte afsløringer, ligesom i den retorik af afsløring, udstillen og tildækning vi så hos den galante Venus, og som læseren inviteres med ind i (Alpers 39). Venus er dermed en bevægelig form, som først den tahitianske kvinde dernæst Tahitis landskab og natur læses, men ikke fastholdes i. Hos Bougainville henviser Venus til et Arkadien, som både fungerer som en temporalisering af afstanden mellem Europa og Tahiti, hvor det andet sted betragtes som en anden tidsalder i vores egen historie, og som en spatialisering af historien, f.eks. doktrinen om at verdenshistorien begynder i Asien, fortsætter i Europa, mens Stillehavet som en helt 'ny' verdensdel på mærkværdig vis er undtaget historisk udvikling. Men Venus er også, sådan som han skriver i et tilføjet kapitel, tatoveret på sine balder, hendes lyse hud skyldes anvendelsen af en stråhat og er ikke en mystisk spejling af den klassiske forestilling om Venusgudindens marmorglatte hud. Tahiti som en lokalitet, der sammenfattes i billedet af Venus, indeholder en mangfoldighed af steder, hvoraf nogle findes på verdenskortet, andre i retorikken, i naturvidenskaben eller kunsthistorien.

\section{Kulturrelativistisk komparation}

Den ledende naturhistoriker på James Cooks anden jordomsejling er Johann Reinhold Forster, der sammen med sin søn George Forster skriver de mest ambitiøse og systematiske rejsebeskrivelser fra denne tidlige æra af opdagelser i Stillehavet. 
Med Johann Reinhold Forsters Observations Made during A Voyage round the World (I780) tages skridtet fuldt ud mod en moderne videnskab efter forbillede i Linné og Buffon.

Johann Reinhold Forster takker i forordet en række notabiliteter for deres kritiske medvirken og anfører en lang række klassiske og moderne tekster, han har måttet konsultere, hvorfor det har trukket ud med at få rejsebeskrivelsen færdig til udgivelse. Men denne omhu har været strengt nødvendig, for emnet har været "naturen i dens videste betydning; Jorden, Havet, Luften, den Organiske og den Animerede Skabelse, og i særdeleshed den klasse af væsner, hvortil vi selv tilhører” (Forster 9). Formålet er at bidrage med en menneskehedens historie, hvor hidtidige forsøg kun har været fragmentariske og desuden har lidt under den mangel, at de er blevet formuleret inden for højt civiliserede nationer, som jo har fjernet sig fra deres oprindeligt tilbagestående stade. Mens netop øerne i Stillehavet tilbyder sammenligninger mellem forskellige udviklingsstadier og dermed giver et billede af menneskets universelle historie. Rejsebeskrivelsen er dermed intet mindre end en forskudt og spejlet version af encyklopædien, hvor observationer inden for alle kendte discipliner, geologi, mineralogi, zoologi, sammenlignende sprogstudier, fysik osv. af genstande og fænomener på New Zealand eller Tahiti og andre øer i Stillehavet i princippet kan akkumuleres til en total og global viden om verden.

Fremgangsmåden er hver gang en tværfaglig og sammenlignende metode, der hovedsageligt sammenholder økulturerne for at bestemme deres relative udviklingsniveau, men også trækker referencer til antikken. Analysen beror gennemgående på den udbredte klimateori, bl.a. sammenligninger mellem ildlændere og grønlændere eller danskere og laplændere, og som sætter de frugtbare, varme og tropiske øer med Tahiti som hovedeksempel øverst på udviklingsstigen, mens Ildlandet må kalde på Forsters medfølelse og håb om, at Forsynet inden længe vil løfte de indfødte i disse kolde egne ud af deres barbariske samfund. Modsætningen er "de strålende egne i de tropiske lande", hvor Forster "føler den mægtige indflydelse af den storslåede kilde af æterisk lys, der bringer glæde til enhvers hjerte” (Forster 2I7). Tahiti er velsignet med en frugtbar jord og et klima, som kombineret med øens fysik og placering i relation til naboøer har givet de bedste mulighedsbetingelser for dannelsen af en lykkelig nation.

Johann Forsters beskrivelse er et mønstereksempel på encyklopædiens kumulative, ophobende stil, der lægger lag på lag til eksisterende viden, men derved også bestandigt indføjer nye lag i lagene, som endnu ikke er tilstrækkelig belyst til at kunne indgå i den totaliserende strategi, f.eks. spørgsmålet om hvorfor brysterne hos kvinder på Tahiti ikke er så flade og penduløse som på øerne i det vestlige Stillehav. Den universalistiske horisont for hans viden bliver for hvert skridt og $\mathrm{i}$ hver passage relativeret $i$ et næsten labyrintisk netværk af henvisninger og partikulariteter. Men man kan også betragte værket som den første tekst, der konstituerer Stillehavet som et særskilt forskningsområde, og netop ud fra en forestilling om øerne som de dele, der hver især rummer et væsentligt billede af det hele. New Zea- 
land, Tahiti, Marquesasøerne, Påskeøen osv. er hver især betragtet som nationer, dvs. selvberoende antropologiske systemer, hvis udviklingstrin kan stipuleres ud fra økokritiske parametre som befolkningstæthed, forholdet mellem ressourcer og forbrug, graden af arbejdsdeling samt de afgørende klimatiske og geofysiske betingelser. Øerne rummer alle delkomponenterne i menneskehedens historie og spejler de universelle principper i deres særlige indretning af samfundet. At få adgang til den viden, som øerne gemmer på om universets indretning, kræver samtidig et blik for deres indbyrdes forskellighed som "nationer". Og dermed markerer Forsters bidrag i virkeligheden en begyndelse for den kulturrelativisme, som Herder senere formulerer filosofisk, og som i det 20. århundredes antropologi netop med særlig tydelighed viser sig i feltstudier på øer. Øer er i det komparative perspektiv særegne og autonome kulturer, mens de i det universelle perspektiv er fraktale dele af menneskehedens universelle historie.

\section{Globale komparationer}

Diderots Supplément au Voyage de Bongainville er som nævnt enestående ved i sin dialogiske form både at udtrykke en rationel kritik af skikke, uanset hvor de er lokaliseret på kloden, og samtidig undgå både en reference til universalistiske værdier som grundlag for denne kritik og en kulturrelativistisk respekt for og dermed inddæmning af selvberoende kulturer. I Diderots mange bidrag til Raynals mammutværk Histoire des deux Indes (I770), den første samlede oversigt over europæisk kolonisering og et sidestykke til Den store franske Encyklopadi, fremgår det desuden med stor tydelighed, at Diderot også er en af I70o-tallets skarpeste kritikere af kolonialismen. Mens Diderot udtrykker anerkendelse af opdagelsesrejsende som Bougainville, der bereder en åbning af verden og tilvejebringer ny viden om menneskehedens mangfoldige væsen og livsbetingelser, er han stærkt kritisk over for kolonisering som erobring af land og undertvingelse af indfødte, tydeligst $i$ beskrivelsen af den blodige erobring af Amerika og i protesten mod alle former for slaveri, f.eks. i artiklen "Om negrenes slaveri" i sjette bind af Histoire des deux Indes.

Den fysiokratiske oplysningstænkning, vi så eksempel på hos Johann Reinhold Forster, konstruerede et olympisk overblik over menneskehedens klimatiske, geografiske og filosofiske historie og udskilte i den proces mængder af selvstændige nationer, som kunne sammenholdes relativistisk og fordeles på en evolutionistisk udviklingslinje. I modsætning hertil er Diderot skeptisk over for begrebet om det nationale. I stedet opfordrer han til ægteskaber på tværs af racer, så kreolkvinder gifter sig med franskmænd og franske kvinder med kreolmænd, og at de sammenblandede familier alle bosætter sig med deres børn i et tredje land, f.eks. Amerika. Dermed skulle ifølge Diderot også de forskellige tænkemåder blive både beriget og harmoniseret og leve i indbyrdes fred ikke som nationer, men som samfund. Den økonomiske parallel til, at kroppene tilstås en fri global bevægelighed, men ikke ret til erobring, er Diderots opfordring til øget global samhandel, "commerce". Men som en pointe, der ligger i forlængelse af Diderots optagethed af Tahiti, betragtede 
Raynal ikke kommers som en del af kolonialismen, men som dens modsætning. Histoire des deux Indes er et forsvar for handel og kommers, forstået som en udveksling af goder mellem frie og lige individer, der udvikler mennesker og samfund, vendt mod kolonialismen, der indebærer erobring, vold og undertrykkelse. ${ }^{\mathrm{I}}$

Denne pointe videreføres i I8oo-tallet af tilhængere af frihandelsdoktrinen, som ikke sigter mod at forbedre mennesket gennem udbredelse af universelle rettigheder, men ud fra en antagelse om at øget kommers i ordets betydning af både handel og samkvem skaber en bedre verden. Var det ikke for spaniernes indolens og orientalernes despotisme, skriver Raynal, ville hele verden og alle folk således være forenet med hinanden gennem handel (Jimack og Mander). - Eller rettere genforenet for under tankegangen ligger Buffons doktrin om at kontinenterne og oceanernes spredte øer engang i tidernes geologiske morgen har været én sammenhængende plade, hvilket også Diderot henviser til i Supplément, hvilket underbygges med henvisning til, at man trods den enorme afstand mellem arkipelagerne ved Tahiti og New Zealand taler det samme sprog. Kommers og frihandel skal altså samle den verden, som kolonisering og jordpladeforskydninger har fragmenteret, og Stillehavet vil i et fremtidigt perspektiv netop kunne udfylde denne historiske rolle ved at genskabe forbindelseslinjer mellem den gamle og den nye verden.

De to meget forskellige modeller for komparation hviler på to forskellige opfattelser af øen: Den kulturrelativistiske model, vi beskrev hos Forster, opfatter dem som isolerede helheder, autonome kulturer, "nationer", enheder for antropologiske feltstudier eller som ideelle økosystemer, baseret på en antagelse om en grundlæggende dikotomi mellem ø og hav. Mens den "pastorale" model hos Bougainville og Diderot opfatter forskellene mellem her og der som et bevægeligt og heteronomt spil af perspektiver og antager en kontinuitet mellem $\varnothing$ og hav, en betoning af at verden er struktureret arkipelagisk, og at havet er en historisk foranderlig strøm af forbindelseslinjer og netværk. Et moderne eksempel er de såkaldte Pacific Rim Studies, hvor stillehavsøerne er genstand for en historieskrivning, hvis perspektiver skifter alt efter om det er pejlepunkter i Syd- og Nordamerika, Rusland, Kina, Japan eller Australien, der betragtes som oceanets periferi (Dirlik).

I Stillehavet (på samme måde som i Arktis) er geopolitik i stigende omfang artikuleret som økopolitik med en intensiveret tilstedeværelse ikke mindst fra Kina og USA i de fora, hvor øernes påtrængende økoudfordringer er til debat. Tidligere identitetspolitiske markeringer af både regionale, nationale og kontinentale territorier bliver udfordret af nye og skiftende postnationale fællesskaber. - Skal f.eks. Tuamotusatollerne, der trues af snarlig forsvinden, definere sig som del i bestræbelserne på at etablere en uafhængig polynesisk nation med Tahiti som hovedø, eller søge en transnational polynesisk identitet, der inkluderer Hawaii og New Zealand,

I Anthony Pagden. "The effacement of difference". After Colonialism. Imperial Histories and Postcolonial Displacements. I30. Pagden henviser også til Montesquieus ideal om "doux commerce”. En tilsvarende læsning findes i Fabienne-Sophie Chauderlot "Prolégomènes à un anti-colonialisme futur: Histoire des deux Indes et Supplément an Voyage de Bongainville de Diderot". 
eller positionere sig som vedhæn til den franske EU-repræsentation og udvikle en mere aktiv tilstedeværelse i EU's økonomiske og klimamæssige programmer?

Stillehavet er i dette magtspil mellem hovedsageligt amerikanske og kinesiske interesser ikke længere afgrænset i klart definerede sfærer for indflydelse, og slet ikke at forstå som en sum af selvstændige nationer med selvstændige nationallitteraturer, f.eks. i form af kanoniserede romaner, men er et hav af øer, der gennemstrømmes af fortællinger og historie i det udvidede felt.

Walter Veit kunne i "James Cook and Comparative Literature" (1972) beskrive opdagelsesrejserne i Stillehavet som en urscene for den komparative litteraturforskning, hvor Frankrig, England og Tyskland viste deres nationale særpræg gennem de forskellige måder, som rejseberetningerne blev modtaget på i de respektive landes vadested mellem Oplysning og Romantik. Mens Veits perspektiv her klart var den gamle komparatismes kosmopolitisme på basis af nationale strømninger og indflydelser, en variant af den kulturrelativistiske model, har jeg her søgt at fremhæve de muligheder for at tænke globale komparationer 'pastoralt', som det enorme materiale også indeholder. David Damrosch forsøger i artiklen "Rebirth of a Discipline: The Global Origins of Comparative Literature" at promovere disciplinen verdenslitteratur ved at opspore den komparative litteraturvidenskabs oprindelse i slutningen af I8oo-tallet og tendenser, der vendte sig mod de både kosmopolitiske og nationalistiske træk, der lå i videreførelsen af Goethes "Weltlitteratur”. Men verdenslitteratur er ikke svaret på de udfordringer i den globale situation, som komparativ litteraturhistorieskrivning står over for i dag. Man må Ioo år længere tilbage, til Bougainville og Diderot, for at finde forbilledlige modeller for komparation, sådan som disse beskrives i antologien Global French (20I0). I introduktionen hertil skriver Susan Rubin Suleiman og Christie McDonald, at globale komparationer både må forlade det eksklusive fokus på litterære enkeltværker, kanon og kanonkritik, som ligger i verdenslitteraturdisciplinen, og samtidig udarbejde andre begreber og kategorier end dem, der ligger i den postkoloniale traditions dikotomier mellem center og periferi, nation og koloni etc.. - Genstanden er derimod selve globaliseringens spatiale og temporale dynamikker og de foranderlige fysiske, geografiske og geopolitiske rum, som litteraturen i det udvidede felt både skaber og bestemmes af.

Verdenslitteratur som videreførelse af komparativ litteratur hviler i grunden på samme problematiske logik som Johann Forsters tidlige kulturrelativisme, hvor autonome, lukkede verdner, nationer eller tekster sættes over for hinanden på et grundlag af skjulte universalistiske standarder. Komparativ litteratur på postlitterære betingelser er dermed læsninger, der vedstår sig den "perplexitet” (Mcdonald og Suleiman), som fremkommer ved at se ting, tekster og landskaber fra flere bevægelige perspektiver på samme tid, akkurat som i rokokoens pastorale. 


\section{LITTERATURLISTE}

Alpers, Paul. What is Pastoral? Chicago: Chicago UP, 1996.

Auerbach, Erich. "Verdenslitteraturens filologi". Verdenslitterer kritik og -teori. Red. Mads Rosendahl

Thomsen. Aarhus: Aarhus Universitetsforlag, 2008.

Bernheimer, Charles. Comparative Literature in the Age of Multiculturalism. Baltimore: Johns Hopkins UP 1995.

Bougainville, Louis-Antoine de. Voyage autour du monde, par la frégate du Roi La Boudeuse et la flûte l'Étoile; En I766,I767,I768 \& I769. Red. Jacques Proust. Paris: Gallimard, 1982 [I771].

Bougainville, Louis-Antoine de. Voyage autour du monde. Red. Michel Bideaux og Sonia Faessel. Paris: Presses de l'Université Paris-Sorbonne, 200I.

Bougainville, Louis-Antoine de. The Pacific journal of Louis-Antoine de Bongainville I767-I768. Red. John Dunmore. London: Ashgate 2000.

Global French. A New Approach to Literary History. Red. Christie McDonald, Susan R. Suleiman. New York: Columbia UP, 2010.

Culler, Jonathan. "Whither Comparative Literature". Comparative Critical Studies, Vol. 3 (2006).

Dahl, Per og Svend Erik Larsen. "Comparative Literature in Scandinavia: Issues and Methods".

La litterature comparée dans le monde: Questions et methodes Vol. II. Red. Lisa Block de Behar. Montevideo: ICLA, 2000.

Damrosch, David. "Rebirth of a Discipline: The Global Origins of Comparative Studies". Comparative Critical Studies 3 (2006).

Diderot, Denis. "Supplément au voyage de Bougainville". Akwres philosophiques. Red. Paul Vernière. Paris: Gallimard 1964.

Dirlik, Arif. What Is a Rim? Critical Perspectives on the Pacific Rim Idea. Boston: Rowman and Littlefield Publishers, 1998.

Forster, Johann Reinhold. Observations Made during A Voyage round the World. Red. Nicholas Thomas, Harriet Guest og Michael Dettelbach. Honolulu: University of Hawai'i Press 1996.

Huyssen, Andreas. "Modernismens geografier i en globaliserende verden". Verdenslittercer kritik og teori. Red. Mads Rosendahl Thomsen. Aarhus: Aarhus Universitetsforlag, 2008.

Hyde, Melissa. Making Up the Rococo. François Boucher and His Critics. Los Angeles: Getty Research Institute, 2006.

Jauss, H.R. "Litteraturhistorie som udfordring til litteraturvidenskaben". Vark og laser. Red. Michel Olsen. Kbh: Borgen, I98I.

Jimack, Peter, Jenny Mander. "Reuniting the World: The Pacific in Raynal's Histoire des deux Indes". Eighteenth-Century Studies vol. 4I, no. 2 (2008).

Krieger, Murray. Words about words about words. Baltimore, Md: Johns Hopkins UP, I988.

The Global Eighteenth Century. Red. Felicity A. Nussbaum. Baltimore: Johns Hopkins UP 2003.

Pagden, Anthony. "The effacement of difference”. After Colonialism. Imperial Histories and Postcolonial Displacements. Red. Gyan Prakash. Princeton: Princeton UP 1995.

Chauderlot, Fabienne-Sophie. "Prolégomènes à un anti-colonialisme futur: Histoire des deux Indes et Supplément an Voyage de Bongainville de Diderot”. Interpreting Colonialism Red. Byron Wells, Philip Stewart. Michegan: Michegan UP 2004. 
Lee, Natasha. "Planetary Perspectives in Enlightenment Fiction and Science" i Global French. Red.

Christie McDonald. New York: Columbia UP, 2010.

Perkins, David. Is Literary History Possible? New York: Johns Hopkins UP, 1992

Pratt, Mary-Louise. Imperial Eyes: Travel Writing and Transculturation. London: Routledge, 1992.

Saussy, Haun. "Exquisite Cadavers Stiched from Fresh Nightmares". Comparative Literature in an Age of Globalization. Red. Haun Saussy. Baltimore: Johns Hopkins UP 2006.

Sørensen, Hans Meinert. Tekst, fortolkning og historicitet. Århus: Modtryk 1998.

Captain James Cook, Image and Impact: South Seas Discoveries and the World of Letters. Red. Walter Veit.

Melbourne: Hawthorn Press, I972. 